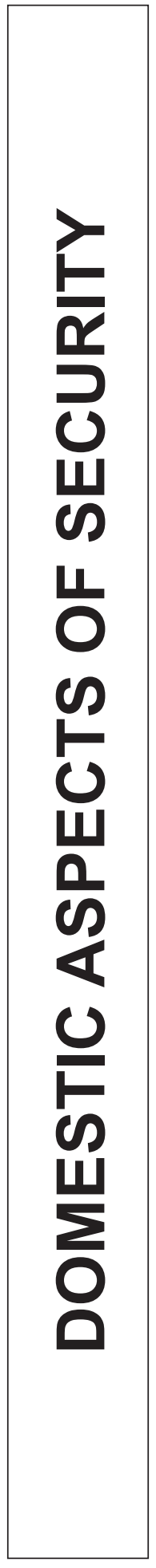



Mikhail BURDA

Russian Presidential Academy of National Economy

DOI : $10.14746 /$ ps.2019.1.12 and Public Administration

https://orcid.org/0000-0003-1520-3882

\section{Irina GERASIMOVA}

Financial University under the Government of the Russian Federation

https://orcid.org/0000-0002-7643-6068

\section{Margarita OCHACHA}

Russian Presidential Academy of National Economy and Public Administration

https://orcid.org/0000-0002-2587-4260

\section{MIGRATION POLICY AS INSTRUMENT OF ENSURING NATIONAL STATE SECURITY}

In addition to the existing demand in labour market and demographic changes, migration is increasingly perceived as a need, not an opportunity. However, migration completely prevents compensation of the negative impact of the existing demographic changes caused by low birth rate in the European countries. Immigration is not a solution to the problems connected with ageing of the European societies and it could not substitute for economic reforms. But immigration can make a significant contribution to minimizing the negative impact of processes of increase in the proportion of senior generation representatives in the structure of the European societies.

Nowadays, migration has become increasingly dependent on global political processes in the modern world. Not only political crises, military or ethnic conflicts, but also the increasing difference in the economic capacity of states act as a starting point of population shift. According to the UN, the world's number of migrants and refugees has reached 277 million people, economic or labour migrants alone - 164 million. About 24\% of them are in the developed countries of Europe, 23\% - in North America (Dobrov, 2018).

There are certain criteria of a state that could be considered quite attractive to immigrants: the existing needs of the labour market, which is not filled by internal resources; various crises in the countries of origin of migrants, as well as historically developed ethno-cultural migration routes.

Modern researchers on population migration distinguish the following stages of the migration process:

- identification and formation of prerequisites for migration;

- the implementation of migration movements related to the changes in legal status;

- the integration into a new society (permanent or temporary) (Voloch, 2015: 7-16).

Despite the fact that the first stage is carried out by a migrant both, as conscious and under the influence of certain pressures (economic situation, military or ethno-cultural 
conflicts, etc.), in the second and third stage, the migrant anyway changes the legal status in another state (a foreign worker, a refugee, a tourist, etc.) (Ravenstein, 1989: 241-305).

Increased migration flows to some extent makes it possible to level the existing deficit in the labour market, while migration to economically prosperous European countries on a modern scale clearly reveals certain risks, including the risks of illegal migration. Illegal migration can be described as a process of entry of citizens of one country to another indefinitely, in order to stay or transit, in violation of the laws regulating the entry and exit procedure, or transit through its territory.

The right of the state to regulate migration processes by law is one of the functions of the state, which allows to a certain extent to contribute to its geopolitical, economic and demographic interests. In order to implement this function, the state exercises its authority by issuing, or conversely - refusing to issue certain permission documents (visas, work permits, residence permit, citizenship) to foreign citizens, allowing them to legalize their status. A state, within the framework of the implementation of its migration policy, combines migration preferences and migration barriers regarding citizens-migrants from other states, depending on its interests.

It is the state authorities that form and implement the migration policy, on which the society places the responsibility for effectively countering the threats to public safety and national security arising in this regard (Burda, 2015: 84).

Taking into account the current political and economic situation in the world, global processes of people movement related to illegal migration could be attributed to the main challenges and threats to the stability and security of states and their political systems. Considering that, in terms of profitability, illegal business connected with the movement of migrants, ranks third after drugs and arms smuggling, one should pay increased attention to countering crimes in this area.

\section{MIGRATION CRISIS IN EUROPE AND EUROPEAN POLITICIANS}

Various military and political conflicts in the Middle East, the Balkan region and Africa have had a significant impact on migration processes in modern Europe. The organization of ethnic unrests in France, Belgium, Great Britain, the participation of migrants in terrorist organizations and commission of terrorist acts, the enormous flows of illegal migrants and refugees have shaken the model of multiculturalism and boosted the popularity of nationally oriented Eurosceptics and political forces using anti-emigrant rhetoric (Langberg, 2017).

A significant part of the European society with conservative views critically perceives the people of another culture and ethnicity, who are in mass migration, and these people, in their opinion, have an impact on the blurring of the state and national identity of European peoples. Thus, the leader of the Netherlands Party for Freedom, Geert Wilders, in this regard, put forward the thesis that in the near future Europeans will have the prospect of "the genocide of traditional cultural values" (Raknes, 2017).

The migration crisis and the need for sovereignty from the European Union in migration policy predetermined a significant increase in the electoral popularity of 
such parties as the Freedom Party (Austria), Fidesz (Hungary), Alternative for Germany (Germany), the Lega Nord (Northern League) (Italy), the Party for Freedom (Netherlands), The National Rally (France), Freedom and Direct Democracy (Czech Republic), the Swedish Democrats (Sweden), and others. As a rule, an electoral basis of such political parties are pensioners, youth and the middle class from poor regions, who feel the social pressure of migrants, and are exposed to unemployment because potential workplaces are taken by migrants.

Thus, modern European right-wing parties not only maintain their traditional electorate, but also actively play on the field of European socialists, who traditionally advocate the preservation of the existing generous system of state social protection and other socialist gains of the 20th century.

In this regard, attention should be paid to the success that the right-wing "Alternative for Germany" achieved in the parliamentary elections in September 2017 with the result of $12.6 \%$ taking the third place overall. It should be noted that this political party had never been widely supported in German society and gained only $4.7 \%$ of the vote in the previous elections.

The "Alternative for Germany" is the only political force in the country that advocates a strict and total restriction of migration, social and financial support for migrants. Thus, the party managed to consolidate the active voting of residents of the east of the country, who are dissatisfied with the migration policy of Angela Merkel. Primarily Saxony and Thuringia, where according to opinion polls almost $80 \%$ of local people have a negative attitude to Islam and migrants (Funke, 2016: 184).

However, the "Alternative for Germany" took the first place in the most economically problematic German land - Saxony.

Ivan Krastev, the head of the Centre for Liberal Strategies in Sofia, considering the impact of the migration crisis on the unity of the European Union, draws attention to the significant dynamics of growth of ideological confrontation between the states of the East and West of Europe. "National loyalty, which was already thought to have died and buried, has returned to present-day Europe with much noise" (Krastev, 2017: 128).

However, the anti-emigrant rhetoric of European political parties and individual politicians is caused not only by the renaissance of "national loyalty," but also by criticism of the migration policy of the European Union, which was not able to provide security and traditional way of life for Europe, and turned out to be ineffective in facing the challenges of massive illegal migration. This was especially sensitive for European countries, through which the routes of illegal migrants pass. So one of the leaders of the Visegrad Group, Hungarian Prime Minister Viktor Orbant said: "There are currently two camps in the European Parliament: one is headed by Macron, who leads the forces that support immigration. On the other hand, we want to stop illegal immigration" (Pelosi, 2018).

In this regard, it is necessary to note the principled negative position taken by the countries of the Visegrad Group (Hungary, Poland, Slovakia and the Czech Republic) on the issue of quota distribution of refugees throughout the European Union. Also, the above-mentioned states refused to sign the UN "World Pact on Safe, Orderly and Regulated Migration," thereby joining the position of the United States, Austria, Italy, 
Switzerland, Australia, Israel, Bulgaria and the Baltic States, which also motivated their refusal because of their concerns for national security and the fight against illegal migration.

As opposed to right-wing populists and conservatives, the liberal, socialist and other similar parties, as well as European globalist sinecures, as a rule support consistent liberalization of migration policy, since they see the migrants as their future voters. The overwhelming majority of European migrants, and especially second-generation migrants who are already citizens of the new homeland, traditionally support political forces, advocating liberal migration policies, social programmes for the poor and the development of a "multicultural" environment.

Thus, we can agree with PatrickJ. Buchanan, who argues that: "Modern migration processes are opposing the interests of two significant social formations of humanity - nations and corporations. The 'managers' of supranational corporations promote the ideas of blurring the national borders and sovereignties of the states, imposing their multi-level integration models. The conductors of such ideas in the war for the deprivation of nations of freedom and independence are various international supranational associations, corporate-dependent institutions of civil society, and individual politicians" (Buchanan, 2003).

Another factor influencing the critical attitude towards migrants of a substantial part of the European society are not the most successful attempts of local authorities to socialize the so-called "migrant communities." At the same time, the communities themselves have steady tendencies not only towards an increase in the number of their members, but also an increase in political influence, at least, at the level of municipal authority.

For example, the "migrant communities" of such cities as Hamburg and Bremen (both are in Germany) are recognized as political forces of the regional format. Different agreements and memorandums of interaction, and also development of a system of religious institutions and holidays, are concluded with these communities (Khenkin, 2015: 137-155).

However, it is necessary to note the rather closed nature of the "migrant communities," forming on the basis of diaspora associations. Arriving migrants formed a diaspora and places of compact residence in large cities, then appropriate infrastructure appeared around them, local residents gradually moved to calmer or more prestigious places, as a result of which the connection between migrants and the host society was broken and the migrants went into the framework of diaspora networks, national and religious traditions. The absence of other forms of unity among migrants besides religion provides fertile soil for radicalism. Despite the fact that the first generation of Muslim migrants promoted the ideas of integration into European society and culture, coming young people and second-generation migrants (often already citizens of European countries) are increasingly exposed to confrontation with the host society.

Thus, already at an early stage, emerged the problem of the association of migrants with the social rules within the diaspora and the lack of integration with the way of life of the new homeland (Ivanova, 2012: 28-34).

Consequently, despite the developing globalization of integration in Europe under the European Union, the first global migration crisis has demonstrated the absence of 
"European unity." The multiculturalism policy in Europe turned out to be ineffective in terms of the integration of migrants into the host society and latently strengthened the radicalization of the second and third generation migrants' views who, being Europeans on passport, did not become Europeans mentally. A number of European states, which are on the southern and eastern borders of the EU, emphasized the impact of the migration crisis on the level of security not only in individual states, but also the European Union as a whole. And another part of the states, which had not previously faced such global migrations of the population, also opposed the "open door" policy, seeing in migration and migrants a threat to the traditional foundations of the social and political life that had been formed over the years. Despite the tolerance shown by a certain part of European society, another, not a smaller part of society still shares the classical conservative ideals and views the migration crisis as the clash of civilizations described by S. Huntington (Huntington, 1996).

\section{INTEGRATION MODELS OF AUSTRIA, THE CZECH REPUBLIC AND RUSSIA WITHIN THE FRAMEWORK OF PRAGUE PROCESS}

In the framework of the Prague Process Action Plan in 2013-2015, the Russian Federation, together with the Czech and Austrian partners, implemented the project: ERIS (Development of Joint Principles, Procedures and Standards on Integration Policies between the Russian Federation and European partners in the context of the Action Plan Prague process). On the results of the project, there was a guide on the principles, procedures and standards of integration policy within the project.

Taking into account a large number of non-indigenous people already living in the territories of the ERIS partner countries (the Czech Republic, Austria and the Russian Federation) and other European countries on a long-term or permanent basis, the discussions on the functioning of immigrant integration programmes and the effectiveness of integration policies are on the agenda when considering any issues related to migration.

Recipient countries use different immigration models, facing integration problems of the arrived migrants. In Austria, prevails the immigration for the purpose of obtaining a residence permit or citizenship, and migration for family reunion plays a relatively large role. In the Czech Republic and the Russian Federation, labour migrants dominate and most of them can be officially classified as temporary or seasonal migrants. However, in practice in the Czech Republic there is already a tendency towards long-term and/or permanent immigration. According to the statistics in the Russian Federation a large number of "temporary" labour migrants have been in the country for more than a year (The Ministry of Internal Affairs of the Russian Federation, 2019).

Thus, not only the length of stay, but also the socio-cultural composition of immigrant groups, emphasize the importance of integration policy.

In Austria, among non-citizens of the European Union, citizens of Turkey and the Western Balkan countries form the largest immigrant communities. A large proportion of immigrants in the Czech Republic are citizens linguistically and culturally close to it, namely Ukraine and the Russian Federation. However, the Czech Republic also 
receives a large number of migrants from Vietnam, with whom there is no cultural or linguistic affinity. Moreover, a large number of labour migrants occupying low-skilled and unskilled jobs in the cities of the Czech Republic come mainly from the rural areas of their countries, and it often creates additional cultural barriers for successful integration.

In the Russian Federation, labour immigration from the countries of the former Soviet Union was perceived as a great benefit, since migrants knew the state language of the Russian Federation and were close to its population in their mentality. At the same time, the content of immigration flows to the Russian Federation has changed: the current generation of migrants, especially from Central Asian countries, unlike their parents, has no longer close linguistic, social and cultural ties with the host society. As a result, labour migrants who come to the Russian Federation often do not have the education necessary to work in Russia, and in many cases do not even speak Russian at a basic level.

Taking into account the above, recognition of the growing importance of an effective integration policy is reflected in the improvement of the legal framework and measures to manage migration flows adopted by all countries.

It should be noted that migrant integration measures are described in national legislation on migration policy and migration strategies, and are also taken into account when developing integration programmes and initiatives at the state, regional and local levels.

However, it should also be remembered that the integration policy is based not only on the successful process of adaptation of migrants to the social conditions of the recipient countries, but also constitutes an indispensable tool for ensuring the communication of cultures and peaceful relationships between various groups within society.

Thus, the integration policy can influence international terrorism and extremism, illicit traffic in narcotic drugs and psychotropic substances. Obviously, the listed issues are the mains of the country's national security.

In the Russian Federation, ensuring national security is a priority of the state policy.

The emergence of new forms of illegal activities, in particular with the use of information, communication and high technologies are also connected with uncontrolled and illegal migration, human trafficking, drug trafficking and other manifestations of transnational organized crime (Указ Президента).

In the Russian Federation, for ensuring economic security, the main efforts are directed to elimination of imbalances in economy, territorial development, labour market development, transport, information, social and educational infrastructures, formation of new geography of economic growth, new branches of economy, centres of industry, science and education, activation of fundamental and applied scientific research, improvement of quality of the general, professional and higher education, improvement of national investment and financial institutions, stimulation the migration of production from other countries to Russia.

In order to counter threats to economic security, state authorities and local governments, in cooperation with civil society institutions, implement the state socio-economic policy, including, among other things, balancing the interests of indigenous 
people and labour migrants, including foreign citizens, taking into account their ethnic, linguistic, cultural and religious differences, improvement of migration registration, reasonable territorial distribution of labour migrants based on the needs of the regions in the workforce.

It should be noted that integration is a bilateral process, the success of which can be ensured only by the interaction of migrants and representatives of host societies. On the one hand, there are concerns that not all immigrants are willing and/or able to adapt and integrate. On the other hand, there is a lack of understanding of the living conditions of migrants, and there is also xenophobia towards them from the majority of the population.

Consequently, integration measures should not only be focused directly on foreign migrants, but also be aimed at promoting intercultural dialogue, as well as improving the acceptance of migrants by society.

For example, successful integration into Austria implies that foreign migrants could speak German at a level sufficient for successful self-realization in the labour market, professional development, education, and interaction with public organizations. In addition, a successfully integrated migrant should be financially independent, respect the law and the basic principles of the European and Austrian legal systems and social values. At the same time, society itself must be characterized as open and socially mobile for migrants. It should allow the individual to live freely and not be discriminated on the basis of origin, language or skin color.

The Austrian integration model involves five important points: knowledge of the German language as the basis for successful integration; education for children; success in the labour market; increase in employment of female foreign migrants; providing an opportunity for municipalities to commit themselves to the implementation of programmes for the integration of foreign citizens.

The main goal of the integration policy of the Czech Republic is to ensure the independence and self-sufficiency of immigrants. In particular, a migrant should be fully involved in the life of society, able to make decisions independently on issues affecting various aspects of his life and the lives of those he takes care of. An important component of integration is the formation of the desire of migrants to act without reliance on the state or other institutions of power. Thus, the integration policy should contribute to the growth of foreigners' knowledge of their rights, the formation of their sense of responsibility for the performance of their duties; the formation of the ability to self-orientation in the new environment, customs and lifestyle of the host society; the growth of knowledge of the Czech language; the growth of social and economic independence; understanding where and how they can be helped in a critical situation.

The most important condition for effective social adaptation and subsequent integration into the society of foreign citizens is that the Russian Federation recognizes the knowledge of the language of the host state, the fundamentals of the state-legal structure, values, history, cultural traditions and norms of behaviour. Providing this condition not only strengthens the unity of society, contributes to the entry of all members of society into a single legal field, but also contributes to ensuring the legitimate interests, rights and freedoms of both Russian and foreign citizens. 
Analyzing the migration trends of most European countries, we can conclude about the need for the quickest implementation of measures for the integration of foreign citizens in the framework of individual integration processes. This not only implies the application of measures to integrate a foreign citizen immediately upon his arrival in the country of destination, but also measures to prepare immigrants for quick adaptation to the conditions of the destination country even before they enter or assessment of ability of migrants to adapt quickly to the conditions of the host society.

In 2011, Austria introduced the points-based system for migrant workers, which was called the "Red-White-Red Card." This is a new point system, which is based on the assessment of such personal qualities of a migrant as: qualifications, work experience (in Austria), age, learning English and German in Austria. Spouses, registered partners and children under 18 of a third-national country, who have received a "RedWhite-Red Card" must prove their knowledge of German at a basic level even until entry to Austria. Only family members of highly qualified specialists are exempt from this requirement. In addition, Austria is constantly preparing information packages containing all the necessary information about staying in the country.

The Czech Republic uses a similar approach. In Ukraine, Moldova and Georgia, the authorities of the Czech Republic carried out targeted information campaigns using local media, consular departments and other information channels describing the possibilities and conditions for immigration to the Czech Republic.

Recent changes in Czech law provide the access to integration programmes for all migrants, including newcomers. And it is progress compared with the previous period, when such programmes were focused only on migrants legally residing in the country for more than one year. The Czech Republic is also intensifying work on the implementation of programmes for the integration of migrants during their stay in the country of origin. Measures for integration into the pre-migration period include providing potential migrants with general information about the conditions of legal residence of immigrants in the Czech Republic, the risks associated with migration, as well as contact information of relevant institutions in the Czech Republic ("predeparture package"). ${ }^{1}$

\section{MIGRATION POLICY AND NATIONAL SECURITY IN THE RUSSIAN FEDERATION}

The Russian Federation also pays essential attention to training of potential migrants in countries of origin. Negotiations are underway to conclude bilateral agreements on the organized recruitment of labour migrants with the states that serve as the main sources of flows of this category of citizens.

Russia is a rather popular centre of migration attraction in the world, the second after the United States, and the first in the post-Soviet area (Voloch, 2016: 159). In 2018, Russia was the most popular among citizens of Uzbekistan (2.4 million), China

1 This part of the article is written based on the series of research conducted in 2019 at the expense of the budget resources by the state task to the Financial University under the Government of the Russian Federation. 
(1.7 million), Tajikistan (1.2 million), Ukraine (1.15 million), Kirghizia (0.5 million). However, if the citizens of China, stated tourism as the purpose of the entry, then people from post-Soviet stated - work (The Ministry of Internal Affairs of the Russian Federation, 2019).

Considering the high migration activity of citizens of the Republic of Uzbekistan, the Government of the Russian Federation and the Government of the Republic of Uzbekistan on April 5, 2017 signed an agreement on organized recruitment of Uzbekistan citizens for temporary employment in the Russian Federation. The peculiarity of the above-mentioned international agreement is the possibility of implementing targeted (to a specific employer on the territory of the Russian Federation) attraction of demanded (previously selected and prepared in accordance with the requirements of the Russian employer) foreign labour and return migration of workers after the expiration of their employment contract. The agreement also necessarily contains the obligations of the governments of the source countries on the training of migrants or citizens of their countries before leaving for Russia, in order to provide their subsequent successful adaptation. It can be said that the Russian-Uzbek experience of organizing the attraction of foreign citizens for temporary work activity synthesized a number of successful European practices and models. It can be said that the Russian-Uzbek experience of the organized recruitment of foreign citizens for temporary work activity synthesized a number of successful European practices and models.

In October 2018, V. V. Putin, the President of the Russian Federation adopted the concept of the state migration policy of the Russian Federation for 2019-2025. This document has updated the goals and objectives in the field of migration, facing the state authorities of the Russian Federation and interested social organizations.

Non-state actors are actively involved in the political management of migration processes: international and regional non-governmental and non-profit organizations, trade unions, political parties, megalopolises, human rights and religious organizations, transnational and private corporations, universities, migrant associations and diasporas, independent experts, the media, the Internet, employers' associations, as well as intermediary institutions specialized in delivering various services to migrants.

This document expands the mechanisms of desired migration not only within the framework of organized recruitment of foreign labour, but also migration of Russianspeaking compatriots, specialists with skills and qualifications necessary, young scientists, etc.

At the same time, special attention is paid to the mechanisms for protecting national security, as well as preventing the use of the Russian Federation as one of transit points in migration flows to Europe (Voloch, Suvorova, 2017: 49).

This condition is achieved through the implementation of intergovernmental agreements on readmission, which have been concluded by Russia with all the states of the European Union, the states of the former Soviet Union and China, Vietnam and some other states.

The basis of the readmission agreement is the consent of the state to accept its citizens back into its territory (and, in some cases, foreigners who have previously been or have lived in that state), who are subject to deportation from another state. At the same 
time, migrants who commit the following types of violations of migration legislation fall under readmission:

- carrying out illegal labour activities;

- illegally entered the country;

- used forged documents;

- staying on the territory of the state after the expiry of their visa, or the period of visa-free stay (for states with a visa-free order of entry into the territory of Russia).

Also, as one of the mechanisms for ensuring national security, the Russian Federation uses the institution of the prohibition of entry of foreign citizens, which shows its effectiveness. This ban concerns foreign citizens in relation to whom there is information about their involvement in the activities of terrorist organizations that have been previously expelled or deported from the Russian Federation, who have violated the migration legislation of the Russian Federation, committed crimes of a criminal and administrative nature in the Russian Federation. Each year about 200 thousand of people are added to this list. Obviously, the term of prohibited entry into Russia is different, to someone the entrance can forever be closed, and to some for several years.

Using the example of the given research, it can be noted that the problem of migration, as a phenomenon, affects many areas of society. In the political sphere, it acts in conjunction with the security of the country, its geopolitical interests and international authority. The European experience of the ill-conceived "open-door" migration policy revealed the existing social problems that were used by conservative parties, Eurosceptics and right-wing populists.

Thus, uncontrolled and illegal migration today is a real threat to the national security of any state. It is partly latent in nature and this requires a coordinated approach to solving the tasks set not only by the interested state authorities, but also by the active participation of various institutions of civil society, as well as scientific understanding of interrelation of migration and ongoing political processes.

\section{REFERENCES}

Buchanan Patrick J., State of emergency: The Third World Invasion and Conquest of America, https:// archive.org/details/State-of-Emergency-Pat-Buchanan (12.03.2019).

Burda M. A. (2015), Risks of illegal migration as threat of national security of Russia, "PolitBook", No. 1 .

Dobrov D., Миграционный пакт ООН расколол мировое сообщество, https://inosmi.ru/ politic/20181213/244226982.html (12.03.2019).

Funke H. (2016), Von Wutbürgern und Brandstiftern: AfD - Pegida - Gewaltnetze, Verlag für Berlin - Brandenburg, Berlin.

Huntington S. P. (1996), The Clash of Civilizations and the Remaking of World Order, Simon and Schuster, New York, NY.

Ivanova Е. А. (2012), Вызовы мультикультурного общества в современном мире: политологический анализ зарубежных и российских сочиологических опросов, „Vestnik RUDN. Seriya Politologiya", No. 1. 
Khenkin S. M., Kudryashova I. V. (2015), The Integration of Europe's Muslims in its Political Aspects, „Polis. Political Studies”, No. 2. DOI: 10.17976/jpps/2015.02.09.

Krastev I. (2017), After Europe, University of Pennsylvania Press, Philadelphia.

Langberg Øystein K., Populister og nasjonalister tar makten i øst. Migrantkrisen har endret Europa fundamentalt, mener forfatter, https://www.aftenposten.no/verden/i/e9bRM/Populister-ognasjonalister-tar-makten-i-ost-Migrantkrisen-har-endret-Europa-fundamentalt_-mener-forfatter (12.03.2019).

Nesterchuk O., Khalbaeva A. (2015), Political management of migration processes: subject-activity approach, "PolitBook", No. 1.

Pelosi G., Europa, l'asse Salvini-Orbán si salda contro migranti e Macron, https://www.ilsole24ore. com/art/notizie/2018-08-28/europa-1-asse-salvini-orban-si-salda-contro-migranti-e-macron203224.shtml?uuid=AEA05UgF\&refresh_ce=1 (12.03.2019).

Raknes K. (2017), Nederlands frykt for Eurabia, https://www.aftenposten.no/meninger/kronikk/i/ Ba6P7/Nederlands-frykt-for-Eurabia--Ketil-Raknes (12.03.2019).

Ravenstein E. G. (1989), The laws of migration, "Journal of the Statistical Society”, Vol. 52 (2).

The Ministry of Internal Affairs of the Russian Federation, https://xn--b1aew.xn--p1ai/Deljatelnost/ statistics/migracionnaya/item/15851053/ (12.03.2019).

Volokh V. A. (2015), Population shift as object of scientific research: essence, modern treatments and classification, "PolitBook", No. 1.

Volokh V. A. (2016), Forced migration in Europe: the condition, problems and solutions in Russia, "Vlast", T. 24, No. 1.

Volokh V. A., Suvorova V. A. (2017), The issues of institutional provision of the state migration policy, "Vlast", T. 25, No. 3.

Указ Президента РФ от 31.12.2015 N 683 “О Стратегии национальной безопасности Российской Федерации", http://www.consultant.ru/cons/cgi/online.cgi?req=doc\&base=LAW\&n=19166 $9 \& \mathrm{fld}=134 \& \mathrm{dst}=100016,0 \& \mathrm{rnd}=0.532575882815391 \# 03060994222299811$ (12.03.2019).

\begin{abstract}
In the article, the authors analyse the relationship of political processes, migration policy and national security of the state. The methodological basis of the research is dialectical, comparative and institutional methods. The dialectical method revealed the dynamics, current regularities and contradictions in the formation of the state migration policy. The comparative method contributed to identify characteristic features of the migration policy formation of some EU countries and Russia, taking into account the transformation of political systems. The institutional method allowed exploring the interaction of public authorities with other institutions of civil society. In order to process the empirical evidence, quantitative and qualitative research methods were used. The factors of the migration attractiveness of the state, the stages of the migration process and migration risks are considered. In this regard, special attention is paid to the migration crisis in modern Europe. It also analyses the growth factors of the popularity of right-populist parties and the idea of the sovereign migration policy of individual member states of the European Union. Special attention is paid to the description of the implementation plan for the "Prague Process" mechanisms on the example of the integration mechanisms of migrants to Austria and the Czech Republic, the participation of government bodies and civil society institutions in these mechanisms. Some features of the migration system of the Russian Federation are also considered in the context of ensuring
\end{abstract}


national security. The research presents and analyses some statistical data on migration in Russia and global migration in the world.

Keywords: migration policy, national security, labour market, economic development, demographic development, human resources, public administration, political process, migration management

\section{POLITYKA MIGRACJI JAKO INSTRUMENT ZAPEWNIENIA BEZPIECZEŃSTWA PAŃSTWA}

\section{STRESZCZENIE}

W artykule autorzy analizują związek procesów politycznych, polityki migracyjnej i bezpieczeństwa narodowego państwa. Podstawę metodologiczną badań stanowi metoda dialektyczna, porównawcza i instytucjonalna. Metoda dialektyczna ujawniła dynamikę, prawidłowości i sprzeczności obecne w kształtowaniu polityki migracyjnej państwa. Metoda porównawcza pozwoliła określić charakterystyczne cechy sposobów kształtowania polityki migracyjnej w niektórych krajach UE i Rosji, z uwzględnieniem transformacji systemów politycznych. Metoda instytucjonalna pozwoliła zbadać interakcje władz publicznych z innymi instytucjami społeczeństwa obywatelskiego. W celu przetworzenia danych empirycznych zastosowano metody badań ilościowych i jakościowych. Uwzględniono czynniki atrakcyjności migracyjnej państwa, etapy procesu migracji i ryzyko migracji. W związku z tym szczególną uwagę zwrócono na kryzys migracyjny we współczesnej Europie. Przeanalizowano także czynniki wzrostu popularności partii prawicowo-populistycznych oraz ideę suwerennej polityki migracyjnej poszczególnych państw członkowskich Unii Europejskiej. Szczególną uwagę zwrócono na opis planu wdrażania mechanizmów „Procesu praskiego” na przykładzie mechanizmów integracji migrantów w Austrii i Czechach oraz udział organów rządowych i instytucji społeczeństwa obywatelskiego w tych mechanizmach. Omówiono także niektóre cechy systemu migracyjnego Federacji Rosyjskiej w kontekście zapewnienia bezpieczeństwa narodowego. Artykuł przedstawia i analizuje pewne dane statystyczne dotyczące migracji w Rosji i na świecie.

Slowa kluczowe: polityka migracyjna, bezpieczeństwo narodowe, rynek pracy, rozwój gospodarczy, rozwój demograficzny, zasoby ludzkie, administracja publiczna, proces polityczny, zarządzanie migracjami 